End of the road
Loan trouble could
be the last straw for
chimp facility
$p 248$

\title{
United States pledges to rethink rejection of fusion experiment
}

Geoff Brumfiel, Washington

The United States may be poised to rejoin ITER, the international project to build an experimental magnetic fusion reactor, which it abandoned three years ago.

After several months of renewed interest in the project at the White House, John Marburger, President Bush's science adviser, confirmed that the United States is reviewing its involvement in ITER. "I definitely think that our participation should be reconsidered," he told a meeting of reporters on 8 January.

The United States, Japan, Russia and the European Union began designing a powerful new fusion experiment, then known as the International Thermonuclear Experimental Reactor, after US president Ronald Reagan and Soviet leader Mikhail Gorbachev endorsed the idea at a summit in 1988.

Fusion researchers want the energy emitted from ITER to surpass the energy put into it - a goal that has eluded them for over 50 years. After 10 years of planning, the team arrived at a design for a massive doughnutshaped machine more than twice the size of any existing fusion device.

But ITER's projected \$10-billion price tag, together with technical concerns over the design, drained support in the United

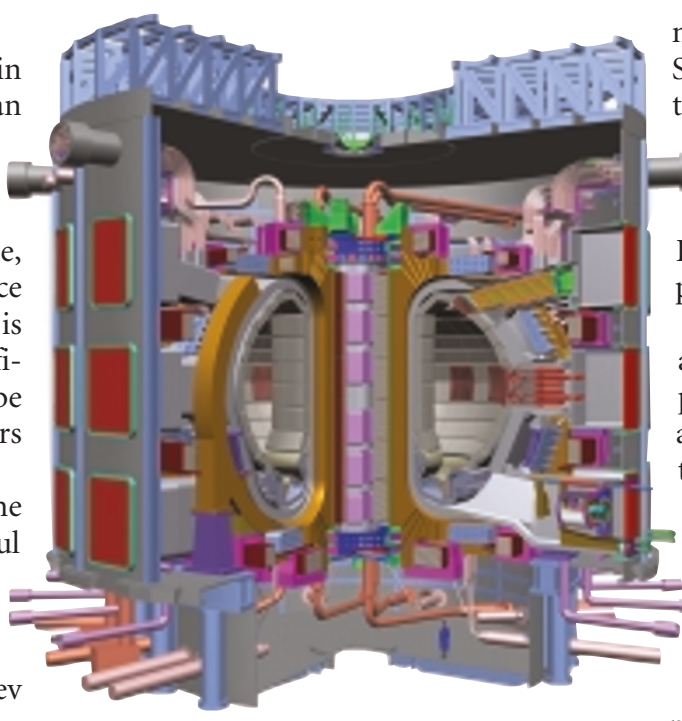

minority member, respectively, of the House Science Committee, wrote to energy secretary Spencer Abraham asking him to send an observer to this year's negotiations on ITER's construction. In his reply, Abraham promised to review the Department of Energy's stance on the project "in the next few months".

Project supporters hope that the Bush administration's general support for fusion power, its desire for visible political cooperation with its allies in the wake of 11 September, and revisions made to ITER's design since 1999, can combine to entice the United States back to the project.

After a reduction in the scale and scope of ITER, the project is now estimated to cost $\$ 4.2$ billion. The United States' reconsideration comes as ITER's participants begin negotiations on the facility's construction. Within the next year, the collaboration is due to select a site and decide how the costs should be divided up.

"The participants are working against a very tight schedule," says Jean-Pierre Rager, spokesman for the European negotiating team. If the United States were to rejoin, Rager encourages it to do so by June this year. "The more these negotiations advance, then the more difficult it is for

\section{Protests mark threatened closure of medical school}

\section{Alison Abbott, Berlin}

Clinical researchers have responded with alarm to a clause in the new Berlin state government's coalition agreement that pledges to close the medical faculty of the Free University and to remove university status from its Benjamin Franklin Clinic.

Over 4,500 researchers, clinicians, patients and members of the public demonstrated against the closure last Friday.

Since its reunification, Berlin has been home to two major research hospitals. The second is located at the Charité Hospital, and belongs to east Berlin's Humboldt University. Berlin's post-reunification governments have already rationalized many of the duplicated departments (see Nature 380, 278; 1996). In its election campaign, the PDS - the reformed communist party, which has now formed a governing coalition with the Social Democrats - proposed a merger of the two faculties, but neither coalition party had previously suggested that either should be closed entirely.

Closure of the Free University's medical school would save Berlin 95 million euros (US\$85 million) per year, according to the new government. But Martin Paul, the faculty's dean, says that closure would also mean the loss of 25 million euros that researchers bring in as external grants every year, as well as the jobs of $\mathbf{5 0 0}$ highly qualified staff.

The new science and culture minister, the PDS's Thomas Flierl, has publicly confirmed that he intends to proceed with the plan, although since the demonstration his party has indicated a willingness to consider arguments against closure.

Speculation that the decision to close the Free University's medical school is being driven by east-west rivalry has been fired by a lack of information about the coalition's true motive, according to Paul. 


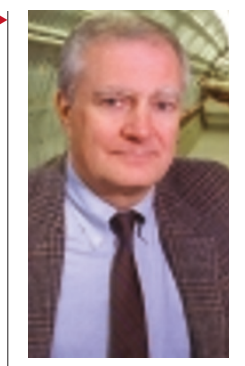

John Marburger thinks a US role in ITER "should be reconsidered". the United States to join," he says.

Japan and Canada have lobbied hard to get the Bush administration to give the project a second look. Canada, which joined the collaboration in 1997, is particularly keen on US participation, which it sees as lending credibility to its bid to host construction.

Fusion researchers are enthusiastic about participation in ITER - provided that additional resources are made available to pay for it. "I think the community is very excited about the possibility of rejoining ITER," says Richard Hazeltine, director of the Institute for Fusion Studies at the University of Texas at Austin. Hazeltine criticized ITER before the US withdrawal, but thinks that the new design addresses his concerns.

The United States still has a long way to go before it could rejoin the project, cautions Anne Davies, director of the Office of Fusion Energy Sciences at the energy department. "We're just at the beginning stages of considering what our position should be," she says. Congress and the administration must pledge their full support before US fusion researchers could resume participation, she adds.

www.iter.org

\section{New-generation cars become old hat as US changes course}

\section{Mark Schrope}

The Partnership for a New Generation of Vehicles (PNGV), a collaboration between the US government and industry to develop more efficient cars, is being replaced with a new programme called Freedom Cooperative Automotive Research, or Freedom CAR.

US energy secretary Spencer Abraham announced the change on 9 January at the Detroit Auto Show, saying that the aim is to "promote the development of hydrogen as a primary fuel for cars and trucks, as part of our effort to reduce American dependence on foreign oil". He added that the PNGV was not cost-effective and was not producing cars that were ready for the showroom.

Set up in 1993, the PNGV was strongly championed by then vice-president Al Gore. Its brief was to produce environmentally friendly prototype cars that were three times as fuel-efficient as those for sale at the time.

The programme included support for research into cars powered by hydrogen fuel cells. But the technology was not available to meet the 2004 deadline, and the PNGV turned to improving existing technologies.

Environmentalists are interpreting the announcement as a retreat from the Clinton administration's commitment to improving fuel economy in the short term. "This is a decision to coddle the US automotive industry, rather than hold it accountable for making real improvements in vehicle efficiency over the coming years," says John DeCicco of Environmental Defense, a New York-based pressure group.

Vernon Roan, director of the fuel-cell lab at the University of Florida in Gainesville and vice-chairman of the National Research Council's peer-review panel for the PNGV, says that the programme had many successes. He notes that the PNGV helped to build bridges between the government and the car industry, produced useful prototypes, and expedited the plans of Ford and General Motors to build and sell fuelefficient 'hybrid' vehicles that run on both petrol and battery power.

In its last review, the panel recommended substantial changes to the PNGV, and Roan says the new programme is consistent with these. "I think it is a good move," he says.

Although details of Freedom CAR have not been finalized, Mick Schwarz, who will lead Ford's participation in the programme, says that it may encourage the construction of infrastructure — including hydrogen filling stations. Schwarz says that he hopes the new programme's budget will match or exceed the $\$ 127$ million given to the PNGV this year. www.ta.doc.gov/pngv

\section{Bank wants money back from troubled chimp facility}

\section{Erika Check, Washington}

A controversial facility in New Mexico that houses chimpanzees for research is facing a serious threat to its survival.

The Coulston Foundation's facility at Alamogordo has weathered years of financial problems, regulatory troubles and animal-rights protests. But now a New Mexico bank has filed a foreclosure lawsuit against the foundation, which houses about 250 chimps. The bank alleges that Frederick Coulston and his foundation have defaulted on over $\$ 1.16$ million in loan repayments.

It is unclear how the foundation will deal with the lawsuit. A representative declined to comment, referring enquires to Coulston's lawyer, who did not return telephone calls.

But Joe Bielitzki, a member of the board of the Scientists Center for Animal Welfare (SCAW), a non-profit group that supports animal research and promotes the humane treatment of research animals, says that researchers are concerned about what will happen to the chimps if the foundation shuts down. "Everybody assumes that the National
Institutes of Health or somebody would pick up the ball and run with it, but the question is who has responsibility for these animals," he says. "It's a really sticky, ugly situation."

Over the past three years, the foundation has lost all of its funding from the National Institutes of Health (NIH). Last year, the NIH's National Center for Research Resources (NCRR) removed the chimps from Coulston's responsibility — although they are still held in the same compound at Alamogordo. In 1999, the NIH decided against renewing two other grants to Coulston.

In July, the US Department of Agriculture alleged that the foundation had violated the Animal Welfare Act before the deaths of two chimps. In October, the Food and Drug Administration refused to grant permits for new experiments by the foundation.

The foundation has also long been a target of animal-rights protesters. Last September, the Animal Liberation Front claimed responsibility for a fire at Coulston's facility.

Space for chimps in the United States is limited, and the issue of their long-term care

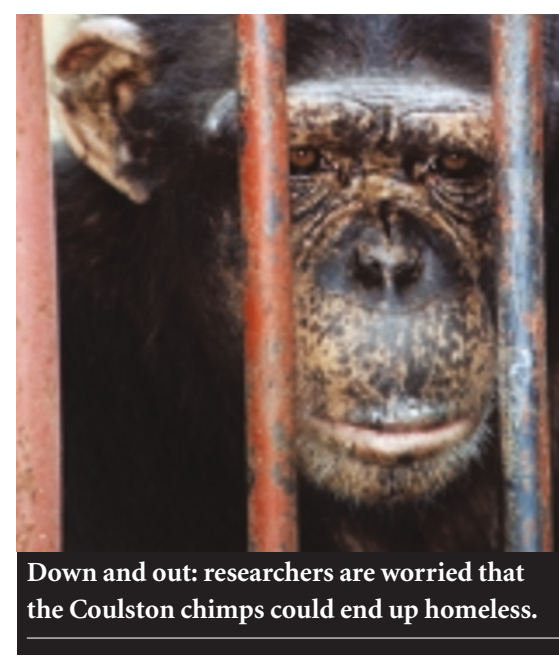

is problematic. Chimps are now rarely used in research, and this year the NCRR will award a \$5-million contract for the construction of a 'sanctuary' to house about 200 retired chimps. However, this will not be ready for several years, and the NIH has already allocated animals to it. 